\title{
Effect of Community Participation in Access to Social Services: A Case Study of Hazina Ya Maendeleo Ya Pwani Approach in Coastal Kenya
}

\author{
Farida A. Hassan ${ }^{1}$, Hilda A. Ong'ayo ${ }^{1}$, Melckzedeck K. Osore ${ }^{2}$, George N. Morara ${ }^{3}$, \\ Christopher Mulanda Aura ${ }^{4}$ \\ ${ }^{1}$ Pwani University, Kilifi, Kenya \\ ${ }^{2}$ Kenya Marine and Fisheries Research Institute, Mombasa, Kenya \\ ${ }^{3}$ Kenya Marine and Fisheries Research Institute, Naivasha, Kenya \\ ${ }^{4}$ Kenya Marine and Fisheries Research Institute, Kisumu, Kenya \\ Email: *naahiyah@gmail.com
}

How to cite this paper: Hassan, F.A., Ong'ayo, H.A., Osore, M.K., Morara, G.N. and Aura, C.M. (2017) Effect of Community Participation in Access to Social Services: A Case Study of Hazina Ya Maendeleo Ya Pwani Approach in Coastal Kenya. Open Journal of Social Sciences, 5, 160-180. https://doi.org/10.4236/jss.2017.511012

Received: October 24, 2017

Accepted: November 27, 2017

Published: November 30, 2017

Copyright $\odot 2017$ by authors and Scientific Research Publishing Inc. This work is licensed under the Creative Commons Attribution International License (CC BY 4.0).

http://creativecommons.org/licenses/by/4.0/

\begin{abstract}
Access to essential social services such as education, health, water and sanitation is a challenge to many residents living in coastal Kenya. Kenya Coastal Development Project (KCDP), a World Bank funded multi-sectoral initiative, implemented its Community Development Fund popularly referred to in Swahili as Hazina Ya Maendeleo Ya Pwani-HMP to improve access to social services among the coastal communities in Kenya. The HMP adopted the Community Driven Development (CDD) approach, whose underlying philosophy is community participation in the delivery of social services and the management of coastal natural resources. In this study, therefore, the extent to which community participation improved access to social services among the coastal communities was assessed using four dimensions of access comprising: availability, affordability, geographical accessibility, and acceptability. A total of 285 respondents from community project beneficiary groups were interviewed across the six coastal counties. There was a significant relationship between community participation and affordability of social services. The results also revealed that there was no significant relationship between community participation and the other dimensions of access namely: availability, geographical accessibility and acceptability of social services. The study indicates that community participation in development interventions is effective in enhancing affordability of social services. Conversely, it cautions that community participation in itself is not necessarily a panacea to fully address
\end{abstract}


the challenge of limitation of access to social services, in terms of availability, geographical accessibility and acceptability of these services. The study concludes that other factors exist besides community participation that influences availability, geographical accessibility and acceptability of social services. Hence, it is difficult to attribute the outcomes of any local service delivery initiative singly on citizen participation.

\section{Keywords}

Community Driven Development (CDD),

Hazina Ya Maendeleo Ya Pwani (HMP), Community Participation

\section{Introduction}

Access is a multi-dimensional concept and currently without one universally accepted definition. In various literature sources however, access has contextually been defined in reference to particular sectors. For example, in the education sector access is narrowly defined as enrolment that conceals vast differences in resource inputs, educational quality, and measurable outcomes [1]. Quality problems mean that many children are silently excluded from meaningful access with low rates of achievement and high risks of dropping out [2]. In the water sector, "access" is defined as the availability of at least 20 litres of water per person per day from an "improved" source within 1 kilometre of the user's dwelling [3]. This definition however only focuses on the distance and quantity of water but says little with regards to adequacy of the 20 litres in addressing the needs of an individual person, considering the different uses of water per household on daily basis. There are many definitions of access to health services with most researchers recognizing that access is related to the timely use of services according to need [4]. In discussing health policy, [5] and [6] defined access as a function with specific dimensions comprising availability, geographic accessibility, affordability and acceptability. [7] and [8] built on this description of access to health services by looking at both the supply and demand sides of service provision as shown in Table 1 . The present study uses a conceptual framework that builds on these longstanding descriptions of access to health services.

Access to social services such as health, education, water and sanitation is a basic human right and a fundamental goal of many nations globally. Social services need to be accessible to all citizens whenever they need it. Regrettably, this is still not a reality for many citizens globally as too often services fail people-in access, in quantity and quality [9]. To address this challenge, World Leaders at the United Nations in September 2000 endorsed the Millennium Development Goals (MDGs) that included targets for education, health, water and sanitation that were to be achieved by 2015 . While globally significant progress was made towards achieving the MDGs, there is still much unfinished business, with more modest accomplishments in a number of goals [10] and thus the challenge of 
Table 1. Dimensions of access to health services indicating supply and demand influence.

\begin{tabular}{|c|c|c|}
\hline No. & $\begin{array}{c}\text { Dimensions of access } \\
\text { [7] }\end{array}$ & $\begin{array}{c}\text { Dimensions of access } \\
{[8]}\end{array}$ \\
\hline 1 & $\begin{array}{l}\text { Geographical accessibility } \\
\text { - User location (S) } \\
\text { - Service location (D) }\end{array}$ & $\begin{array}{l}\text { Geographical accessibility } \\
\text { - Indirect cost to household } \\
\text { transport costs (D) }\end{array}$ \\
\hline 2 & $\begin{array}{l}\text { Availability } \\
\text { - Health workers drugs and } \\
\text { equipment (D) } \\
\text { - Demand for service (D) }\end{array}$ & $\begin{array}{l}\text { Availability } \\
\text { - Waiting time (S) } \\
\text { - Wages and quality of staff } \\
\text { - Price and quality of drugs and other consumables (S) } \\
\text { - Information on health care choice/providers (D) } \\
\text { - Education } \\
\text { - Adequacy (S) }\end{array}$ \\
\hline 3 & $\begin{array}{l}\text { Affordability } \\
\text { - Cost and prices of service (S) } \\
\text { - Household resources (D) } \\
\text { - Willingness to pay (D) }\end{array}$ & $\begin{array}{l}\text { Affordability } \\
\text { - Direct price of service including informal fees (S) } \\
\text { - Opportunity cost (D) }\end{array}$ \\
\hline 4 & $\begin{array}{l}\text { Acceptability } \\
\text { - Characteristics of the health } \\
\text { services (S) } \\
\text { - Users attitude and } \\
\text { expectations (D) }\end{array}$ & $\begin{array}{l}\text { Acceptability } \\
\text { - Management/staff efficiency (S) } \\
\text { - Technology (S) } \\
\text { - Household expectations (D) } \\
\text { - Community and cultural preferences, } \\
\text { attitudes and norms (D) }\end{array}$ \\
\hline
\end{tabular}

Source: Adopted from [7] and [8]. Note: $\mathrm{D}=$ demand side; $\mathrm{S}=$ supply side.

lack of access to basic social services still persists. A second attempt to address these challenge was made again by the World Leaders in 2015, when a new set of targets popularly referred to as the Sustainable Development Goals (SDGs) were crystallized and agreed upon [11]. The SDGs include among others ensuring healthy lives, quality education, availability and sustainable management of water and sanitation for all.

The situation is no different at the Kenya coast where residents are forced to live with the challenge of limited access to essential social services. The region is characterized by low literacy levels compounded by significant gender disparity in literacy with women scoring much lower percentages in the counties of Kilifi, Tana River and Kwale counties [12] [13]. Compared to other regions in Kenya, Coast has fewer schools, which are widely scattered thus more difficult to access, and attendance is further restricted due to lack of transport facilities [14]. Most of the students in the coastal counties, especially Kilifi and Tana River walk for an average distance of $5 \mathrm{~km}$ or more to and from the nearest primary schools [15] [16]. The average distance to the nearest water point in many of the Kenya's coastal counties is $5 \mathrm{~km}$ resulting in difficulty in access to this essential service [15] [16] [17] [18]. Sanitation is a challenge in these counties as the coverage of latrine/toilet is only $50 \%$ in the area and with no proper systems for managing liquid and solid wastes. Less than $10 \%$ of the households disposed their garbage 
or solid waste through organized systems such as the local authorities [16]. The situation is made worse by the fact that about $69.7 \%$ of the coastal population live below the poverty line, making it the second poorest region of the Kenya's eight regional blocks, after North Eastern with 73.9\% [12]. Limitation in access to social services coupled with the high poverty rate undermines the socio-economic wellbeing of the coastal residents.

Government agencies and development partners have implemented many projects and programs in the coastal region that seek to address the challenge of access to social services. However, despite several decades of development funding, access to social services by most coastal residents has remained low. Some of the possible reasons are attributed to the lack of adequate community participation [19] and weak sustainability framework that ensures continuity of service provision and better practice of preservation such as enterprise development [20]. One promising strategy for improving access to social services in Kenya's coastal region is to engage communities in the provision and management of social services. Through a community development fund (translated in Swahili as Hazina Ya Maendeleo Ya Pwani-HMP) developed under the auspices of the Kenya Coastal Development Project-KCDP (a World Bank funded project) coastal communities were engaged in the entire process of identification, development and implementation of projects whose objective was to improve access to social services. According to official KCDP documents, HMP adopted a Community Driven Development (CDD) approach in the delivery of the community projects. The CDD is a typology of participatory approaches popularly defined as a methodology that emphasizes handing over of planning decisions and investment resources directly to community groups and the local government [21].

Historically, programs using the CDD approach grew out of situations of crisis (financial shock, conflict and even natural disasters) and were meant as transitional instruments for service delivery where governments particularly newly installed administrations lacked capacity to deliver services [21]. As such, the approach has been widely used for development purposes mostly in fragile and conflict-affected settings such as Afghanistan, the Democratic Republic of Congo, Myanmar and Somalia [22]. CDD operations have proven successful at reaching and empowering communities, delivering cost-effective infrastructure, enhancing livelihoods, and improving community dynamics [23]. The philosophy behind CDD is that involving communities in local development decisions is not only an inherent citizen's right, but that participation often leads to better use of resources geared toward meeting the needs of the communities [21]. Active participation of society in development is necessary since they are object and also subject of the development, which forms the basis for establishment of participatory development models [24]. The basic premise of the CDD approach is that if individuals and groups are brought together to define common or shared goals and are provided with resources and support, they can work together to 
achieve those goals [22]. Also, by giving "control of decisions and resources to community groups" [25], CDD projects will better meet communities' needs and enhance ownership [22]. It is also hypothesized that engaging in CDD's participatory processes will empower communities, increase capacity for local development and governance and improve social cohesion [26].

Using the CDD approach, coastal communities organized in the form of Community Based Organizations (CBOs) were mobilized and taken through a process of identification and prioritization of community projects that address the challenge of access to social service within their locale [20]. Once the priority community projects were agreed upon, the CBOs prepared grant proposal for financing under the HMP grant mechanism. As this was a great challenge for most CBOs, a proposal template was designed to ease the proposal development task. Additionally, the County Liaison Officers (CLOs), who were HMP staff hired under KCDP and other government staff from the relevant department provided the requisite technical support where needed. Thereafter the proposals were further appraised by HMP county staff in consultation with the line agencies in order to seek possible synergies and avoid conflict with planned agency operations. The grant proposals were screened by senior HMP management team to confirm their conformity with the HMP objectives before being submitted to the Project Vetting Committee-PVC (comprising a wider team of staff drawn from KCDP management, County Government and relevant NGOs). At PVC level, the proposals were reviewed based on their overall impact positive on beneficiary community, and sustainability potential including technical and financial feasibility. The proposals that complied with the aforementioned criteria were approved for funding while those disapproved were returned to the respective $\mathrm{CBOs}$ for correction and resubmission in the subsequent review sessions.

The grants provided for financing the community projects were initially categorized into three levels: large (KShs 1.5 - 3.0 Million), medium (KShs 1.0 - 2.5 Million) and small (KShs 0.5 - 2.0 Million) grants. In the course of implementation of the HMP CDD project, the grant sizes were subsequently reviewed upwards by approximately KShs 0.5 Million within each category to accommodate the huge costs of infrastructural projects proposed by most of the CBOs. The eligibility criterion for applying for the different grant categories was pegged on the experience of the $\mathrm{CBO}$ in project management and overall fiscal discipline. For this reason, more experienced $\mathrm{CBOs}$ applied for the larger grants while the beginners applied for the smaller grants. The successful CBOs were also required to make a $10 \%$ contribution to the total project costs while the HMP grant catered for the difference $(90 \%)$. The grants were released to the CBOs in three tranches where upon demonstration of proper utilization of the initial grant, the subsequent balances were released for execution of the community projects. Throughout the implementation period, the $\mathrm{CBO}$ s received technical support on project implementation as well as regular training on financial and project management. Conditionality for areas where the HMP grants could not be used 
were also set out and this included among others; the payment for recurrent expenditures, purchase of land and projects that are deemed to have adverse environmental and social impacts.

Between 2013 and June 2017, a total of 124 community projects were financed and implemented across the entire coastal region under the HMP CDD approach. Of these projects 58 were of the social service sector providing essential services to local communities in the six coastal counties. This paper therefore examined the influence of community participation in addressing the challenge of access to social services in the project areas. The overall goal was to determine the extent to which the CDD approach improved access to social services among communities in coastal Kenya. Specifically, the study investigated the influence of community participation on: 1) improved availability of social services among coastal communities; 2) reduced physical distance (geographical accessibility) to social services; 3 ) improved affordability of social services; and 4) enhanced acceptability of social services by the local communities.

\section{Methodology}

The study was carried out in the coastal region covering all the six counties comprising Kwale, Taita Taveta, Mombasa, Tana River, Lamu and Kilifi (Figure 1). The coastal region covers an area of $83,603 \mathrm{~km}^{2}$ constituting about 11.5 percent of the total area of the Republic of Kenya with a coastline of approximately 600 $\mathrm{km}$ long, extending from the border with Somalia at Ishakani in the north (Longitude $1^{\circ} 41^{\prime} \mathrm{S}$ ) to the border with Tanzania at Vanga in the south (Longitude $4^{\circ} 40^{\prime}$ S. According to the 2009 population census [12], the coastal region of Kenya has a population of approximately 3.3 Million people with a growth rate of $3.0 \%$. The distribution of the population in the region is largely influenced by rainfall, altitude, agro-ecological setup and administrative policy through which a number of settlement schemes have been created however, majority of the people are concentrated in urban centres [13].

The region is inhabited by a culturally heterogeneous population with the $\mathrm{Mi}$ jikenda being the largest ethnic group composed of nine sub-tribes, namely Giriama, Digo, Rabai, Duruma, Kauma, Chonyi, Kambe, Ribe and Jibana. Other coastal ethnic groups are the Taita, Pokomo, Bajuni, Orma, Sagala and the Swahili. The Kenyan coast also hosts a large migrant population of different ethnic and racial origins [12]. The region is characterized by high poverty rate with about $69.7 \%$ percent of the coastal population living below the poverty line [12]. Besides increasing poverty levels, majority of the coastal residents have limited access to basic social services.

The study population comprised coastal communities who are beneficiaries of the HMP supported community projects. Purposive random sampling was used to identify coastal communities who are beneficiaries of the HMP supported community projects. Proportionate sampling technique was used to identify community members from each county using a sampling frame obtained from 


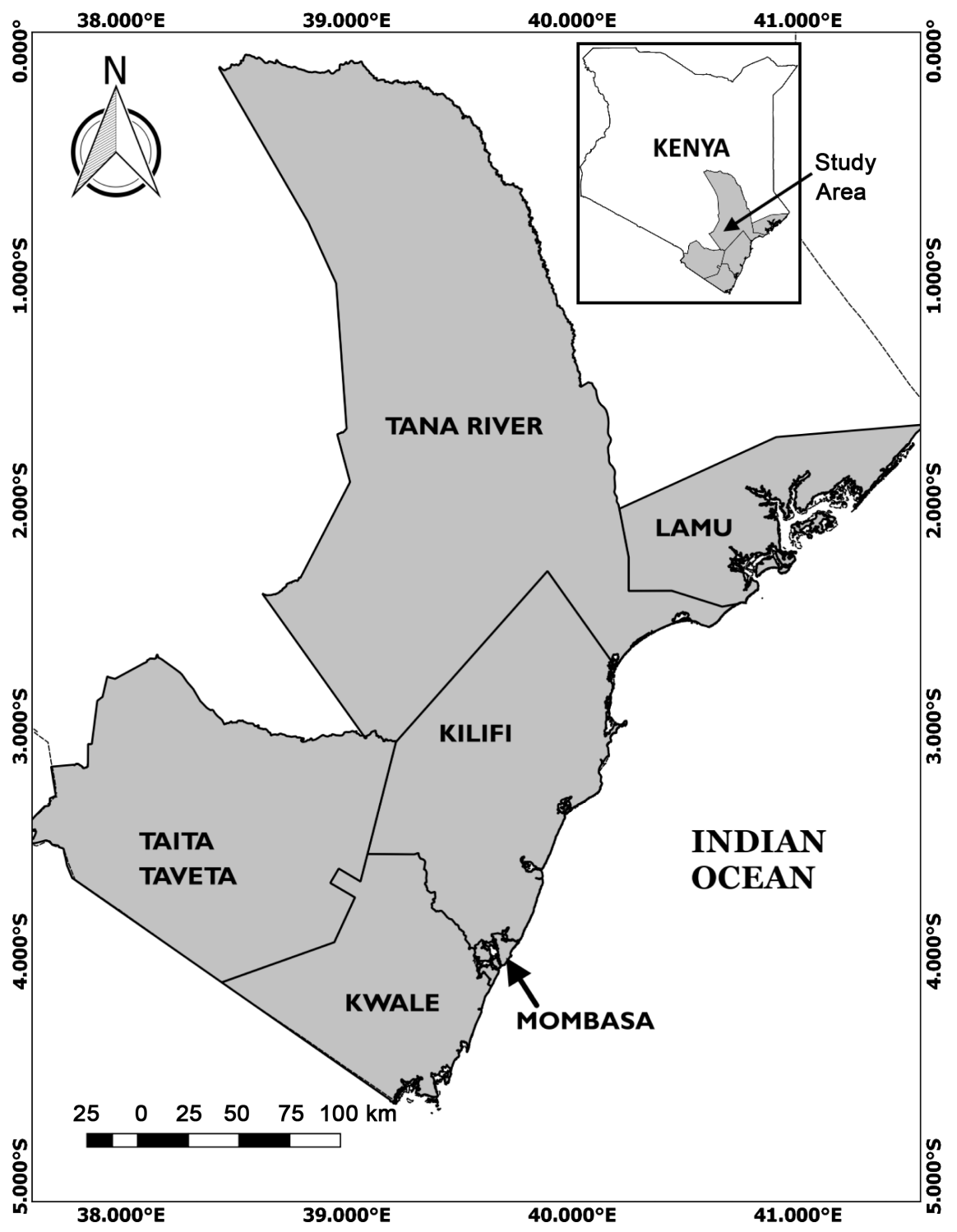

Figure 1. The Kenya coastal region covering all the six counties comprising Kwale, Taita Taveta, Mombasa, Tana River, Lamu and Kilifi where the study was undertaken. Source: $[20]$.

HMP records. Thereafter, a simple random sampling method was used to identify the study sample size comprising 326 respondents. Consent for voluntary participation was sought from each respondent by providing a detailed explanation about the study, assuring confidentiality and anonymity of information collected. Data for the study was collected through the use of semi-structured interviews using a predesigned questionnaire as shown in the Appendix and focus group discussion sessions. Pilot testing of the questionnaires was done to test the robustness of respondents' replies before actual administering. The data from questionnaires were checked for normality and outliers and no violations were detected. The data were edited into specified variables, classified by coding, and entered into Microsoft Excel sheets. The data was transferred into Statistical 
Package for Social Sciences (IBM-SPSS Inc. Version 20.0 IBM Corp. Released 2011, IBM SPSS Statistics for Windows, Version 20.0 Armonk, NY: USA) for analysis to obtain descriptive statistics by use of frequencies and percentages. Inferential statistics was done using cross tabulation and chi-square $\left(\chi^{2}\right)$ goodness of fit between variables. Level of significance was at $p<0.05$. Furthermore, Table 2 shows how the current study measured access to social services in terms of key dimensions.

\section{Hypotheses}

$\mathrm{Ho}_{1}$ : Community participation did not improve availability of social services among coastal communities.

$\mathrm{Ho}_{2}$ : Community participation did not improve affordability of social services among coastal communities.

$\mathrm{Ho}_{3}$ : Community participation did not reduce the physical distance to social services among coastal communities.

$\mathrm{Ho}_{4}$ : Community participation did not enhance acceptability of social services among coastal communities.

\section{Results and Discussion}

\subsection{Socio-Economic Characteristic of Respondents}

Majority (56\%) of the respondents were females, while $44 \%$ were males (Table 3 ). This implies that the selection of the respondents was almost proportionate based on gender. This is important because women play a key role in community development and in particular households. Most of the respondents (53\%) were in the age range of 31 to 50 years, while $40 \%$ were over 50 and $7 \%$ were 20 to 30 years. A negligible percentage of the respondents were below 20 years of age. As for educational level, most of the respondents $(33.7 \%)$ had primary education, while $24.7 \%$ had high school education. A total $7.7 \%$ and $2.8 \%$ had college and university education, respectively. It was worrying to discover that $31.2 \%$ of the respondents were illiterate. These results are in agreement with those of [13]

Table 2. Measuring access to social services.

\begin{tabular}{|c|c|}
\hline Dimension & Aspect to be Measured \\
\hline Availability & $\begin{array}{l}\text { - Adequacy in meeting needs of the family } \\
\text { - Ability to obtain the service throughout the year } \\
\text { (hours of operation, waiting time) }\end{array}$ \\
\hline $\begin{array}{l}\text { Geographical } \\
\text { Accessibility }\end{array}$ & $\begin{array}{l}\text { - Physical distance between the dwelling of the user and } \\
\text { the point of access }\end{array}$ \\
\hline Affordability & - Cost of service \\
\hline Acceptability & $\begin{array}{l}\text { - Quality of the service } \\
\text { - Whether the service meets the socio-cultural expectations } \\
\text { of the user/community (satisfaction with service, } \\
\text { gender, social barriers, ethnic grievances, age) }\end{array}$ \\
\hline
\end{tabular}


Table 3. Socio-economic characteristics of respondents.

\begin{tabular}{|c|c|c|}
\hline Variables & Frequency & Percentage \\
\hline \multicolumn{3}{|l|}{ Gender } \\
\hline Male & 124 & 44 \\
\hline Female & 161 & 56 \\
\hline \multicolumn{3}{|l|}{ Age } \\
\hline$<20$ Years & 3 & 0 \\
\hline $20-30$ Years & 20 & 7 \\
\hline 31 - 50 Years & 151 & 53 \\
\hline$>50$ Years & 111 & 40 \\
\hline \multicolumn{3}{|l|}{ Level of education } \\
\hline Primary school & 96 & 33.7 \\
\hline High School & 70 & 24.6 \\
\hline College & 22 & 7.7 \\
\hline University & 8 & 2.8 \\
\hline Illiterate & 89 & 31.2 \\
\hline \multicolumn{3}{|l|}{ Household size } \\
\hline 1 - 5 Persons & 122 & 42.8 \\
\hline 6 - 10 Persons & 118 & 41.4 \\
\hline $11-15$ Persons & 24 & 8.4 \\
\hline 16 Persons and above & 21 & 7.4 \\
\hline \multicolumn{3}{|l|}{ Occupation } \\
\hline Farming & 183 & 64.2 \\
\hline Fishing & 02 & 0.7 \\
\hline Trading & 54 & 18.9 \\
\hline Formal employment & 23 & 8.1 \\
\hline Others & 23 & 8.1 \\
\hline
\end{tabular}

Field survey, January 2017.

that the illiteracy levels in the Kenya coastal region is high and needs immediate redress. Majority of the respondent (42.8\%) had household size of $1-5$ persons while $31.4 \%$ had $6-10$ persons. Very few respondents (8.4\% and $7.4 \%)$ had household sizes of $11-15$ and above 16 persons, respectively. With respect to occupation, majority (64.2\%) of the respondents were farmers, while $18.9 \%$ were traders, $8.1 \%$ were formally employed, $0.7 \%$ were fishermen. $8.1 \%$ of the respondents were either retirees or unemployed.

\subsection{Community Participation and Availability of Social Services}

The results show that, majority of the respondents (95\%) agreed that they were engaged in the development and implementation of HMP supported community 
projects while very few (5\%) confirmed that they were not engaged (Table 4). With respect to overall availability of social services, which was measured in terms of adequacy and obtainability, $51 \%$ of the respondents indicated that the services were available while the other $49 \%$ confirmed that services were not available. About $54 \%$ of the respondents indicated that the services were not obtainable highlighting challenges such as water rationing by some of the water service providers. In addition, some of the water supply options selected by the community that included water pans and shallow wells tended to dry during the dry spell. This underscores some of the technical challenges related to the feasibility of water supply technology chosen by some of the CBOs. In terms of adequacy, $55 \%$ of the respondents indicated that the services adequately met the household needs while $45 \%$ confirmed otherwise. For instance, it was pointed out that classrooms constructed in the community schools were insufficient to address the needs of the students and as such some of the pupils had to take classes in turns. During FGDs, the project beneficiaries indicated that this challenge was primarily caused by the insufficient funds provided by the HMP project, thus limited full access to educational services in some cases.

The study hypothesised that community participation did not improve availability of social services among coastal communities. However, results of chi-square test (Table 5) showed that the difference is not significant $(\mathrm{n}=285$,

Table 4. Respondents perception on community participation and availability of social service.

\begin{tabular}{ccccc}
\hline \multirow{2}{*}{ Variable } & \multicolumn{2}{c}{ Agree } & \multicolumn{2}{c}{ Disagree } \\
\cline { 2 - 5 } & $\boldsymbol{f}$ & $\%$ & $F$ & $\%$ \\
\hline Community Participation & 270 & 95 & 15 & 5 \\
Obtainability & 131 & 46 & 154 & 54 \\
Adequacy & 156 & 55 & 129 & 45 \\
Total & $\mathbf{2 8 7}$ & $\mathbf{5 1}$ & $\mathbf{2 8 3}$ & $\mathbf{4 9}$ \\
\hline
\end{tabular}

Field survey, January 2017.

Table 5. Relationship between community participation and availability of social services.

\begin{tabular}{|c|c|c|c|c|c|c|}
\hline & Value & df & $\begin{array}{l}\text { Asymp. Sig. } \\
\text { (2-sided) }\end{array}$ & $\begin{array}{c}\text { Exact Sig. } \\
\text { (2-sided) }\end{array}$ & $\begin{array}{l}\text { Exact Sig. } \\
\text { (1-sided) }\end{array}$ & $\begin{array}{c}\text { Point } \\
\text { Probability }\end{array}$ \\
\hline Pearson Chi-Square & $1.872^{\mathrm{a}}$ & 1 & 0.171 & 0.194 & 0.135 & \\
\hline Continuity Correction $^{\mathrm{b}}$ & 1.217 & 1 & 0.270 & & & \\
\hline Likelihood Ratio & 1.904 & 1 & 0.168 & 0.194 & 0.135 & \\
\hline Fisher's Exact Test & & & & 0.194 & 0.135 & \\
\hline Linear-by-Linear Association & $1.866^{\mathrm{c}}$ & 1 & 0.172 & 0.194 & 0.135 & 0.085 \\
\hline $\mathrm{N}$ of Valid Cases & 285 & & & & & \\
\hline
\end{tabular}

${ }^{\mathrm{a}} 0$ cells $(0.0 \%)$ have expected count less than 5 . The minimum expected count is $7.42 ;{ }^{\mathrm{b}}$ Computed only for a $2 \times 2$ table; ${ }^{\circ}$ The standardized statistic is 1.366 . 
$p>0.05)$. The null hypothesis that community participation did not improve availability of social services, was accepted. These findings agree with those of [27] that there are other factors besides citizen participation that equally influence service delivery and therefore attributing local service delivery singly on citizen participation becomes a difficult task. They are also in tandem with those of [28] who observed that the relationship between citizen participation and availability of social services is "conditioned by complex political, historical, social and economic factors" which affect in magnitude and importance. Other studies with similar observations include the work of [29] who stated that "there is no systematic or comparative evidence on whether increased citizen participation in decentralized local governance generates better outputs in provision of education, health, drinking water and sanitation services. Where data is available it is "from single countries and sector or is anecdotal and temporarily specific and highly localized thus rendering generalization problematic". [30] also contends that participation is not always necessarily a panacea to complex social problems as often suggested in the literature to date. The findings complement the discourse by [19] that in the light of increasing importance of CDD and decentralization of public services, there may currently be too large a burden placed on community participation as a cure-al instead of recognizing both its benefits and limitations.

However, there are several other studies whose observations are contrary to the finding above. [31] argues that where communities participate, there are improved school facilities, increased accountability among school personnel, and improved capacity of participants. Together these contribute to increased student access, retention, and academic performance of students. [32] highlights that participatory methodologies are a proven way to provide services where scale and complexity exclude direct control and are more suitable for small local projects where communities lack the necessary skills and social cohesion. This is in complementary with studies of [7] who stated that the key ingredients of success in improving poor people's access to health services include concerted efforts to reach the poor, engaging communities and disadvantaged people, encouraging local adaptation and careful monitoring effects on the poor. Other literatures in this line of thought include [33] and [34]. [21], in the impact evaluation of Indonesia Urban Poverty Program II, indicated an improvement in access to adequate sanitation as a result of the project, in particular for the poor.

\subsection{Community Participation and Affordability of Social Services}

Affordability of social services was measured in terms of cost of service that was categorised in terms of expensive, reasonable and cheap.

Table 6 shows that $50 \%$ of the respondents stated that the cost of the social services provided by their community project was cheap while $34 \%$ felt that the prices were reasonable. Focus Group Discussion (FGDs) revealed that prior to the implementation of the HMP project, the cost of water in some of the communities could go as high as KShs 50 (US\$ 0.5) per 20 litre during the dry season. In 
Table 6. Perception of respondents on cost of social services.

\begin{tabular}{ccccc}
\hline & & $\boldsymbol{f}$ & $\%$ & Cumulative \% \\
\hline \multirow{3}{*}{ Valid } & Reasonable & 98 & 34 & 34.4 \\
& Expensive & 45 & 16 & 50.2 \\
& Cheap & 142 & 50 & 100.0 \\
& Total & $\mathbf{2 8 5}$ & $\mathbf{1 0 0}$ & \\
\hline
\end{tabular}

Field survey, January 2017.

Table 7. Relationship between cost of social service and community participation.

\begin{tabular}{ccccccc}
\hline & Value & df & $\begin{array}{c}\text { Asymp.Sig. } \\
(2-s i d e d)\end{array}$ & $\begin{array}{c}\text { Exact Sig. } \\
(2-\text {-sided })\end{array}$ & $\begin{array}{c}\text { Exact Sig. } \\
\text { (1-sided) }\end{array}$ & $\begin{array}{c}\text { Point } \\
\text { Probability }\end{array}$ \\
\hline Pearson Chi-Square & $8.850^{\mathrm{a}}$ & 2 & 0.012 & 0.011 & & \\
Likelihood Ratio & 7.966 & 2 & 0.019 & 0.019 & & \\
Fisher's Exact Test & 8.169 & & & 0.013 & & \\
Linear-by-Linear Association & $2.422^{\mathrm{b}}$ & 1 & 0.120 & 0.144 & 0.081 & 0.035 \\
N of Valid Cases & 285 & & & & & \\
\hline
\end{tabular}

${ }^{\mathrm{a}} 1$ cells $(16.7 \%)$ have expected count less than 5 . The minimum expected count is 2.37 . ${ }^{\mathrm{b}}$ The standardized statistic is -1.556 .

most of the HMP financed community projects, the highest price charged was ten times less at KShs 5.0 with no price fluctuation between the dry and wet seasons. Similarly in the education sector, community members initially had to cater for the cost of constructing classrooms and paying the teachers' salaries in the community managed schools. However, through the HMP projects, the communities were required to only meet $10 \%$ of the entire cost of constructing the classrooms. It is anticipated that the cost of teachers' salaries will ultimately be transferred to the government once the department of education registers the schools. Very few respondents (16\%) confirmed that the services were expensive. Upon further interrogation, the respondents clarified, they felt that the services were now more expensive because of the newly introduced user fees, which need to be paid to cater for operation and maintenance costs of the community projects. As such the respondents felt that the social services were more expensive than before the implementation of the HMP financed community projects. This feedback was mostly received from water projects where community members were initially drawing water freely from natural sources such as springs and rivers. Additionally in the sanitation sector community members would also resort to open defecation where no costs need to be paid.

The study hypothesised that community participation did not improve affordability of social services among coastal communities. Chi-square test showed the contrary and demonstrated that the difference was significant $(\mathrm{n}=285, p<$ 0.05 ) (Table 7). Thus, it was significant that community participation improved affordability of social services in terms of reducing the cost of social services. The findings mirror the results of [35] that in Cote d'Ivoire, when responsibility 
for rural water supply shifted from the control of Central Government to user groups, break-downs and costs were reduced. The results are in tandem with those of [36] on a study of all community projects under the Kecatamatan CDD program in Indonesia. The study showed that water projects designed to incorporate community participation had much lower failure rates than conventional projects and the costs of the village infrastructure projects were 30 to 50 percent lower than costs in projects using government construction. These results are consistent with those of [37] that the Bamako Initiative implemented in Benin, Guinea, and Mali that put communities in charge of health services (by allowing them to charge fees and manage the proceeds). The initiative improved the access, availability, affordability, and use of health services. After more than 10 years of implementation in these three countries, community-owned services restored access to primary and secondary health care for more than 20 million people.

On the contrary, a different study by [38] revealed that despite the various mechanisms used for targeting the most deserving communities, affordability remained a problem for many of the poorest families. The findings are also similar to a study by [39] conducted in South Africa which confirmed that when community based organizations are responsible for all aspects of the project (design, management, and monitoring), costs per beneficiary are less than half than compared to when the $\mathrm{CBOs}$ are not the decision makers.

\subsection{Community Participation and Reduction in Physical Distance to Social Services}

To measure the influence of community participation on reducing the physical distance to accessing social services the respondents were asked to indicate the distance to the service after the completion of the HMP supported community project.

The results in Table 8 show that majority of the respondents (73\%) indicated that the physical distance to accessing social services has reduced to below $1 \mathrm{~km}$ from previously 5 to $10 \mathrm{~km}$. $27 \%$ of the respondents confirmed that the services are available at a distance of above $1 \mathrm{~km}$. The World Health Organization [9] notes that improved access for social services particularly for safe drinking water is measured by the percentage of the population accessing water within 1 Kilometre of an "improved water source". These results therefore show that majority of the beneficiaries of the HMP financed community projects can now access the service within a distance of $1 \mathrm{~km}$.

The study hypothesised that community participation does not improve geographical accessibility to social services among coastal communities. At $95 \%$ confidence level, it is statistically not significant (Chi-square test, $\mathrm{n}=285, p>$ 0.05 ) that community participation reduced the physical distance to social services (Table 9). The null hypothesis that community participation does not improve geographical accessibility to social services is therefore accepted. The results are in line with those of [40] in their study of a CDD project implemented 
Table 8. Respondents perception on reduced distance to social services.

\begin{tabular}{ccccc}
\hline & $F$ & $\%$ & Valid \% & Cumulative\% \\
\hline Above 1 Km & 78 & 27 & 27 & 27 \\
Below 1 Km & 207 & 73 & 73 & 100 \\
Total & 285 & 100 & 100 & \\
\hline
\end{tabular}

Field survey, January 2017.

Table 9. Relationship between community participation and reduction in physical distance to social services.

\begin{tabular}{|c|c|c|c|c|c|c|}
\hline \multicolumn{7}{|c|}{ Chi-Square Tests } \\
\hline & Value & df & $\begin{array}{l}\text { Asymp. Sig. } \\
\text { (2-sided) }\end{array}$ & $\begin{array}{l}\text { Exact Sig. } \\
\text { (2-sided) }\end{array}$ & $\begin{array}{l}\text { Exact Sig. } \\
\text { (1-sided) }\end{array}$ & $\begin{array}{c}\text { Point } \\
\text { Probability }\end{array}$ \\
\hline Pearson Chi-Square & $2.966^{\mathrm{a}}$ & 1 & 0.085 & 0.132 & 0.081 & \\
\hline Continuity Correction $^{\mathrm{b}}$ & 2.030 & 1 & 0.154 & & & \\
\hline Likelihood Ratio & 2.687 & 1 & 0.101 & 0.132 & 0.081 & \\
\hline Fisher's Exact Test & & & & 0.132 & 0.081 & \\
\hline Linear-by-Linear Association & $2.956^{\mathrm{c}}$ & 1 & 0.086 & 0.132 & 0.081 & 0.055 \\
\hline $\mathrm{N}$ of Valid Cases & 285 & & & & & \\
\hline
\end{tabular}

${ }^{\mathrm{a}} 1$ cells $(25.0 \%)$ have expected count less than 5 . The minimum expected count is 4.11 ; ${ }^{\mathrm{b} C o m p u t e d}$ only for a $2 \times 2$ table; 'The standardized statistic is -1.719 .

by the International Rescue Committee in post conflict northern Liberia. This careful study found no impact of the project on access to public goods or services and more specifically, the authors also found no evidence that the community-driven reconstruction program reduced the distance for households in treatment communities to walk to key social services.

The results contradict the works of [21] obtained during the impact evaluation of the Nicaragua Emergency Social Investment Fund II (FISE). In Nicaragua, terms of access to piped water, FTSE increased the share of households with access to piped water considerably and there was a significant decline in the distance to the water source. The findings are not in tandem with those of [41] that observed that the Bamako Initiative in Benin, Guinea, and Mali raised the population with access to services within $5 \mathrm{~km}$ to $86 \%$ in Benin, $60 \%$ in Guinea, and $40 \%$ in Mali, covering more than 20 million people. Greater access reduced travel costs, and the availability of drugs reduced the need to visit distant sources of care.

\subsection{Community Participation and Acceptability of Social Services}

Acceptability of social services was measured in terms of quality and whether the service meets social cultural expectations of the users/community. The socialcultural expectations entailed issues of gender, convenience of service provision hours, social and ethnic barriers. The results are presented in Table 10. 
Table 10. Perception of respondents on acceptability of social services.

\begin{tabular}{ccccc}
\hline & \multicolumn{2}{c}{ Satisfied } & \multicolumn{2}{c}{ Unsatisfied } \\
\cline { 2 - 6 } & $F$ & $\%$ & $F$ & $\%$ \\
\hline Quality of service & 163 & 50 & 122 & 50 \\
Meeting social cultural expectations of users/community & 164 & 50 & 121 & 50 \\
Total & 327 & 100 & 243 & 100 \\
\hline
\end{tabular}

Field survey, January 2017.

The study found out that half of the respondents (50\%) indicated their satisfaction with the quality and that the services met the socio-cultural expectations of the users and community at large (Table 10). Equally (50\%) of the respondents were also dissatisfied with the quality and confirmed that the social services neither met the quality and the socio-cultural expectations of the individual users and community. Those who were satisfied provided reasons such as having access to piped water, permanent classrooms for their children and access to improved sanitation services. However those who were dissatisfied with the services cited reasons such as lack of better water provision option, they chose to utilize their HMP grant for construction of water pans or shallow wells which provided them with water that cannot be used for drinking. Due to the small grant sizes, only a few classrooms were constructed in each school hence their children still attend school in turns. The sanitation facilities put up through the CDD approach of HMP project were few in each village such that at times waiting to access the service was necessary.

The study hypothesised that community participation did not improve acceptability of social services among coastal communities. It was statistically not significant (Chi-square test, $\mathrm{n}=285, p>0.05$ ) that community improved acceptability of social services (Table 11). The null hypothesis, that community participation did not improve accessibility of social services, is therefore accepted. The findings correlate with those of Bay (2011 citing [42]) that participation is likely to work where government officials (especially politicians) and citizens agree and it is only in such environment that citizen preferences are likely to be taken seriously. The findings relate with those of [43] that the transfer of experiences is usually context specific and an intervention package that repeatedly proved to have a positive effect in one setting may have very different effects in other settings

However, there are several other studies whose observations are contrary to the finding above [44] opine that community participation can result in other outcomes such as better access to health services, more relevant and culturally appropriate services [45]. The findings contradict those of [46] and [47] who reported increased community interest in education, and increased equity in access to education for marginalized groups as benefits of community participation in schools. The results are contrary to those of [48] that if users were directly involved in service design and selection, services were likely to match 
Table 11. Relationship between community participation and acceptability of social services.

\begin{tabular}{ccccccc}
\hline & Value & Df & $\begin{array}{c}\text { Asymp. Sig. } \\
\text { (2-sided) }\end{array}$ & $\begin{array}{c}\text { Exact Sig. } \\
(2 \text {-sided })\end{array}$ & $\begin{array}{c}\text { Exact Sig. } \\
\text { (1-sided) }\end{array}$ & $\begin{array}{c}\text { Point } \\
\text { Probability }\end{array}$ \\
\hline Pearson Chi-Square & $3.761 \mathrm{a}$ & 1 & 0.052 & 0.058 & 0.042 & \\
Continuity Correctionb & 2.770 & 1 & 0.096 & & & \\
Likelihood Ratio & 4.359 & 1 & 0.037 & 0.058 & 0.042 & \\
Fisher's Exact Test & & & & 0.058 & 0.042 & \\
Linear-by-Linear Association & $3.747 \mathrm{c}$ & 1 & 0.053 & 0.058 & 0.042 & 0.034 \\
N of Valid Cases & 285 & & & & & \\
\hline
\end{tabular}

${ }^{\mathrm{a}} 0$ cells $(0.0 \%)$ have expected count less than 5 . The minimum expected count is $5.53 ;{ }^{\mathrm{b}}$ Computed only for a $2 \times 2$ table; ${ }^{\circ}$ The standardized statistic is 1.936 .

their preferences. The findings contradict those of [49] that community participation in rural health service development results in more accessible, relevant, and acceptable services. Lastly, the findings also contradict those of [50] where it is often implied that community participation will result in higher community satisfaction with health services, and indeed better health outcomes.

\section{Conclusion and Recommendations}

The study noted that one of the most powerful and frequently cited arguments in the literature-that community participation can improve access to social services and hence the flow of benefits to citizens-held true for only one dimension of access-affordability. Thus, community participation improved affordability of social services amongst communities in coastal Kenya. This finding helps to create and re-ignite hope of confronting the challenge of access to social services and related problems, which have been a great concern to the coastal residents. As such, given the high poverty level in the region, the affordability of social services may potentially contribute to improved wellbeing of coastal communities. There was no significant relationship between community participation and improvement in availability, acceptability and geographical accessibility of social services at the Kenya coast. Based on this finding, there could be other factors besides community participation that influence accessibility of social services. Therefore, it confirms the difficulty of attributing the local service delivery outcomes singly on citizen participation. However as noted, the HMP financed community projects are quite new to allow for a definitive statements about their overall success or failure in improving the availability, acceptability and geographical acceptability of social services. Furthermore, strong empirically based evidence on the effectiveness of CDD approach is impeded by the lack of good data to measure access to social services compared to a counterfactual scenario-where there was no community participation-within the same context, as was the case in this study. Based on these findings, it is recommended that:

1) The CDD approach is effective in enhancing community participation and 
accountability thus providing an effective mechanism for service delivery in a cost-effective and time-efficient manner. The government should therefore adopt the CDD approach to harness its potential in mobilizing coastal communities to hasten the delivery of essential social services in the region.

2) When engaged through a participatory process, coastal communities can build small-scale water supplies, schools, clinics and sanitation facilities that provide services within their locale. However it was not apparent, how these projects align with the county and national government sectoral plans to deliver social services to communities on a larger scale. As such, mechanism should be put in place to bring on board all the relevant stakeholders including the government agencies so as to coordinate discrete community projects into larger government plans that address the challenge of access to social services on a broader scale.

\section{Limitations of the Study}

Although the methods employed in the research were useful, the study was not without its limitation. The first limitation was the low literacy level of some of the respondents especially in Tana River County, which necessitated deeper probing to enhance respondents' understanding of some of the questions posed. In some cases there was need to translate the questions into $S$ wahili or local dialect to make the questions understandable. As such, some of the responses provided may not have fully captured the perception of some of the respondents. Secondly, there was the problem of limited use of a control group that would provide for comparison of the community's perceptions of access to social service between the CDD and non-CDD approaches currently being applied at the Kenya coast.

\section{Acknowledgements}

The Community Driven Development (CDD) Fund for the Coast translated in Kiswahili as Hazina ya Maendeleo ya Pwani (HMP) presented herein, acknowledges the support and funding provided by The Kenya Coast Development Project (KCDP) as a multi-sectoral development project financed by the World Bank and the Global Environmental Facility (GEF). Kenya Marine and Fisheries Research Institute (KMFRI) provided staff and logistic support. Effort of the CLOs responsible for the six coastal counties under KCDP and that of Driver Titus Fondo for field transportation is acknowledged. The national Government and Coastal County Governments played a key role in releasing staff and resources for this work. Task Tem Leaders Dinesh Aryal and Veruschka Schmidt are appreciated for their moral and technical support.

\section{References}

[1] Keith, M.L. (2007) Improving Access, Equity and Transitions in Education: Creating a Research Agenda. Create Pathways to Access Research Monograph No 1. http://sro.sussex.ac.uk/1828/1/PTA1.pdf 
[2] Manzoor, A. and Altaf, H. (2010) Educational Access in Bangladesh. Country Research Summary.

http://www.create-rpc.org/pdf_documents/Bangladesh_Country_Research_Summa ry.pdf

[3] Evans, D.B., Hsu, J. and Boerma, T. (2013) Universal Health Coverage and Universal Access. World Health Organization.

[4] Campbell, S.M., Roland, M.O. and Buetow, S.A. (2000) Defining Quality Care. Social Science \& Medicine, 51, 1611-1625.

https://doi.org/10.1016/S0277-9536(00)00057-5

[5] Penchansky, R. and Thomas, J.W. (1981) The Concept of Access: Definition and Relationship to Consumer Satisfaction. Medical Care, 19, 127-140. https://doi.org/10.1097/00005650-198102000-00001

[6] O'Donnell, O. (2007) Access to Health Care in Developing Countries: Breaking Down Demand Side Barriers. Cadernos de Saúde Pública, 23, 2820-2834. https://doi.org/10.1590/S0102-311X2007001200003

[7] Peters, D.H., Garg, A., et al. (2008) Poverty and Access to Health Care in Developing Countries. Annals of the New York Academy of Sciences, 1136, 161-171. https://doi.org/10.1196/annals.1425.011

[8] Ensor, T. and Cooper, S. (2004) Overcoming Barriers to Health Service Access: Influencing the Demand Side. Health Policy and Planning, 19, 69-79. https://doi.org/10.1093/heapol/czh009

[9] World Development Report (2004) Making Services Work for Poor People. Oxford University Press, New York.

[10] United Nations Development Programme (2015) The Millennium Development Goals Report 2015.

http://www.undp.org/content/undp/en/home/librarypage/mdg/the-millennium-dev elopment-goals-report-2015.html

[11] Kroll, C. (2015) Sustainable Development Goals: Are the Rich Countries Ready?

[12] Government of Kenya (2008) Kenya Vision 2030: Ministry of Planning, National Development and Vision 2030.

[13] Hoorweg, J., Foeken, D., Obudho, R.A. and Mazrui, A. (2000) Kenya Coast Handbook: Culture, Resources and Development in East African Littoral. African Studies Centre, Leiden, The Netherlands.

[14] Alwy, A. and Schech, S. (2004) Ethnic Inequalities in Education in Kenya. International Education Journal, 5, 266-274.

[15] Tana River County Government (2013) First County Integrated Development Plan 2013-2017.

[16] Kilifi County Government (2013) First County Integrated Development Plan 2013-2017.

[17] Kwale, County Government (2013) First County Integrated Development Plan 2013-2017.

[18] Lamu, County Government (2013) First County Integrated Development Plan 2013-2017.

[19] Khwaja, I.A. (2004) Is Increasing Community Participation Always a Good Thing? Journal of the European Economic Association, 2, 427-436.

https://doi.org/10.1162/154247604323068113 
[20] Aura, C., Hassan, F., Osore, M.K., Musa, S., Morara, G. and Uku, J. (2015) A Comprehensive Public-Private Partnership Concept for Resources Sustainability from a Mega-Project Management Multi-Level Perspective. International Journal of Management and Sustainability, 4, 218-236. https://doi.org/10.18488/journal.11/2015.4.11/11.11.218.236

[21] Wong, S. (2012) What Have Been the Impacts of World Bank Community-Driven Development Programs? CDD Impact Evaluation Review and Operational \& Research Implications. The World Bank, Washington DC.

[22] Bennett, S. and D’Onofrio, A. (2015) Community-Driven Development in Conflict-Affected Contexts: Revisiting Concepts, Functions and Fundamentals. Stability: International Journal of Security and Development, 4, Article 19.

https://www.rescue.org/sites/default/files/document/567/communitydrivenlowresfi nalshereeandalyoscia0.pdf

[23] World Bank (2011) Community Driven Development. Empowering People to Lead Their Development.

[24] Simangunsong, F. and Wicaksono, S. (2017) Evaluation of Village Fund Management in Yapen Islands Regency Papua Province (Case Study at PasirPutih Village, South Yapen District). Open Journal of Social Sciences, 5, 250-268.

[25] Dongier, P., Van Domelen, J., Ostrom, E., Rizvi, A., Wakeman, W., Bebbington, A., Alkire, S., Esmail, T. and Polski, M. (2003) Community Driven Development. In: Poverty Reduction Strategy Paper Sourcebook, Washington DC.

[26] Chase, R. and Woolcock, M. (2005) Social Capital and the Micro-Institutional Foundations of CDD Approaches in East Asia: Evidence, Theory and Policy Implications. Arusha Conference "New Frontiers of Social Policy". http://citeseerx.ist.psu.edu/viewdoc/download?doi=10.1.1.508.2411\&rep=rep1\&type $=\mathrm{pdf}$

[27] Muriu, A.R. (2014) How Does Citizen Participation Impact Decentralized Service Delivery? Lessons from the Kenya Loca; Authority Service Delivery Action Plan (LASDAP, 2002-2010).

https://www.internationalbudget.org/wp-content/uploads/How-does-Public-Partici cipation-Influence-Decentralized-Service-Delivery-Muriu-April-2014.pdf

[28] Cheema, G.S. and Rondinelli, D.A. (2007) From Government Decentralization to Decentralized Governance. In: Cheema, G.S. and Rondinelli, D.A., Eds., Decentralizing Governance: Emerging Concepts and Practices, Brookings Institution Press, Washington DC, 170-188.

[29] Robinson, M. (2007) Does Decentralization Improve Equity And Efficiency In Public Service Delivery Provision? IDS Bulletin, 38, 7-17. https://doi.org/10.1111/j.1759-5436.2007.tb00333.x

[30] Hayward, S., Simpson, L. and Leanne, W. (2004) Still Left Out in the Cold: Problematising Participatory Research and Development. Sociologia Ruralis, 44, 95-108. https://doi.org/10.1111/j.1467-9523.2004.00264.x

[31] Russell, K. (2009) Community Participation in Schools in Developing Countries: Characteristics, Methods and Outcomes. Qualifying Paper. http://files.eric.ed.gov/fulltext/ED519214.pdf

[32] Brett, E.A. (2003) Participation and Accountability in Development Management. The Journal of Development Studies, 40, 1-29. https://doi.org/10.1080/00220380412331293747

[33] Azfar, O., Kähkönen, S., Lanyi, A., Meagher, P. and Rutherford, D. (1999) Decentralization, Governance and Public Services: The Impact of Institutional Arrange- 
ments. A Review of the Literature. IRIS Center, University of Maryland, College Park.

http://siteresources.worldbank.org/INTINDONESIA/Resources/Decentralization/Li t_Review_IRIS.pdf

[34] VanLerberghe, W. and Ferrinho, P. (2003) Civil Society Organizations and the Poor: The Unfulfilled Expectations. Background paper for the WDR 2004.

[35] Hino, T. (1993) Community Participation in "Programme de Restructuration de L'Hydraulique Villageoise” in Côte d'Ivoire. Africa Country Department 11. World Bank, Washington DC.

[36] Wetterberg, A. and Scott, G. (2005) Capitalizing on Local Capacity: Institutional Change in the Kecamatan Development Program. In: Bebbington, A.J., Woolcock, M. and Guggenheim, S., Eds., Practical Theory, Reflective Action: Social Capital and Development Projects at the World Bank, Oxford University Press, New York.

[37] World Bank (2004) CDD Impact Assessments Study: Optimizing Evaluation Design under Constraints.

[38] Gilson, L., Kalyalya, D., Kuchler, F., Lake, S., Oranga, H. and Ouendo, M. (2001) Strategies for Promoting Equity: Experience with Community Financing in Three African Countries. Health Policy, 58, 37-67. https://doi.org/10.1016/S0168-8510(01)00153-1

[39] Adato, M., Timothy, B., Lawrence, H. and John, H. (1999) Participation and Poverty Reduction: Issues, Theory and New Evidence from South Africa. Background paper for World Development Report 2000/2001. International Food Policy Research Institute and World Bank, Washington DC.

[40] Fearon, J., Humphreys, M. and Weinstein, J. (2008) Community-Driven Reconstruction in Lofa County: Impact Assessment. Unpublished manuscript. http://www.columbia.edu/ mh2245/FHW/FHW_final.pdf

[41] Mehrotra, S. and Jarrett, S.W. (2002) Improving Basic Health Service Delivery in Low-Income Countries: "Voice" to the Poor. Social Science and Medicine, 54, 1685-1690. https://doi.org/10.1016/S0277-9536(01)00336-7

[42] Bay, K.E. (2011) Does Participatory Governance Deliver? Citizen Participation and Social Service Delivery in Nicaragua. A Dissertation Submitted in Partial Fulfillment of the Requirements for the Degree of Doctorate of Philosophy in the Department of Political Science at Brown University, Rhodes Island. https://repository.library.brown.edu/storage/bdr:11256/PDF/

[43] Khwaja, A. (2003) A Note on "Measuring Empowerment"-An Economist's Perspective. Paper given at Measuring Empowerment: Cross-Disciplinary Perspectives, The World Bank, Washington DC, 4-5 February 2003.

[44] Preston, R., Waugh, H., Taylor, J. and Larkins, S. (2009) The Benefits of Community Participation in Rural Health Service Development: Where Is the Evidence? 10 th National Rural Health Conference. https://researchonline.jcu.edu.au/5316/1/Preston_Preston_Rural_health.pdf

[45] George, M., Masotti, P., MacLeod, S., VanBibber, M., Loock, C. and Fleming, M. (2007) Bridging the Research Gap: Aboriginal and Academic Collaboration in FASD Prevention. The Healthy Communities, Mothers and Children Project. Alaska Medicine, 49, 139-141.

[46] Bray, M. (1999) The Private Costs of Public Schooling: Household and Community Financing of Primary Education in Cambodia. UNESCO, IIEP, Paris, France.

[47] Rugh, A. and Bossert, H. (1998) Involving Communities: Participation in the Delivery of Education Programs. Abel Project, Creative Associations International, Inc., 
Washington DC.

[48] Isham, J. and Kähkönen, S. (1999) What Determines the Effectiveness of Community-Based Water Projects? Evidence from Central Java, Indonesia on Demand Responsiveness, Service Rules, and Social Capital. The World Bank Social Capital Initiative Working Paper No. 14.

http://siteresources.worldbank.org/INTSOCIALCAPITAL/Resources/Social-Capital -Initiative-Working-Paper-Series/SCI-WPS-14.pdf

[49] Taylor, J., Wilkinson, D. and Cheers, B. (2008) Working with Communities in Health and Human Services. Oxford University Press, Oxford.

[50] Kilpatrick, S. (2009) Multi-Level Rural Community Engagement in Health. Australian Journal of Rural Health, 17, 39-44.

https://doi.org/10.1111/j.1440-1584.2008.01035.x 